\title{
1 RELIGIOUS TOLERANCE IN ETHIOPIA: RHETORIC AND REALITY
}

\section{Mohammed Dejen Assen ${ }^{1}$}

\section{INTRODUCTION}

In academia, especially of Christian writers of Ethiopian religious history, contemporary politicians and the Ethiopian Orthodox Church (EOC), there seems to be a general consensus that Ethiopia's religious past is characterised by peaceful coexistence and tolerance between Muslims and Christians. ${ }^{2}$ Although partly true, the emphasis only on the consensual aspect of the relations not only distorts the conflictual relations, ${ }^{3}$ but also undermines contemporary claims of Muslims for more parity and freedom, as the government and Christians associate their claims with religious intolerance and extremism. The author of this chapter subscribes to the general assertion of peaceful coexistence and tolerance, noting however that it was largely attributable to the forbearance of Muslims and the acceptance of the status quo with no or minimal resistance. Whenever Muslims become assertive in political and economic affairs of the state, their relations with the state and Christians deteriorate.

This chapter examines the religious history of the country in relation to the tolerance and forbearance narratives advanced by the Christians and Muslims respectively. In doing so, the first part of the chapter highlights the religious demography of the country by focusing on Islam and Christianity. The second section will deal with the conflicting narratives of Ethiopia's religious past mainly drawn from the Muslim and Christian perspectives. The third part provides a conceptual framework of tolerance and forbearance in the Ethiopian context and explains the Ethiopian experience of religious coexistence. It also discusses the various discourses of religious coexistence advanced by different sets of actors. Finally, it examines contemporary trends of religious (in)tolerance and appraises some of the policies of the government towards religion.

1 The author is an assistant professor at Addis Ababa University, College of Law and Governance Studies.

2 For the purpose of this chapter, Christianity is to mean only Orthodox Tewahedo Christianity of Ethiopia. It does not include Protestantism, Catholicism and other denominations of Christianity as they were excluded from the benefits that the Ethiopian state provided for Orthodox Tewahedo Christians. According to the 2007 population census, Protestants comprise about $18.6 \%$ of the religious figure of Ethiopia and Catholics are around $0.7 \%$.

3 Hussein A. 2006. “Coexistence and/or Confrontation? Towards a Reappraisal of Christian-Muslim Encounter in Contemporary Ethiopia", Journal of Religion in Africa 36(Fasc. 1):4-22. 


\section{THE RELIGIOUS MAP OF ETHIOPIA}

\section{Orthodox Christianity}

Based on the population and housing census of $2007,{ }^{4}$ Orthodox Christianity constitutes $43.5 \%$ of the total number of the religious composition of the Ethiopian people. Their number decreased roughly by 7\% from the 1994 census results. ${ }^{5}$ Ethiopia was the first country in Africa to host Christianity. It entered the country in the middle of the fourth century $\mathrm{CE}^{6}$ through the "two brothers, Frumentius and Aedesius [of Syria]", ${ }^{7}$ which makes Ethiopia the third country in the world to adopt Christianity after Constantinople and Armenia. ${ }^{8}$ King Ezana, the Axumite King, who was believed to be the first convert to Christianity, established the religion at the state level. A political scientist and historian, John Markakis states that Orthodox Christianity was introduced in the country after the Monophysite doctrine was "condemned as a heresy" by the Catholic Church at the religious Council of Chalcedon. Some groups subscribing to this dogma fled to Axum from the Church of Alexandria, from where the Ethiopian Church used to import Patriarchs until 1959. Those who came to Axum include the nine saints from Syria who later translated the Bible into Ge'ez. ${ }^{9}$ As Markakis noted, the Ethiopian Church then followed the Monophysite creed and later incorporated some indigenous elements in it in an attempt to "indigenise" the religion.

After that time, Orthodox Christianity was the established state religion of Ethiopia. It continued with this status up to the close of the twentieth century. Emperor Haile Selassie I (1930-1974) was the last of the so-called Solomonic Dynasty rulers who legally intertwined Christianity and the Ethiopian state in an "unholy marriage". ${ }^{10} \mathrm{He}$ did his level best to blend Christianity, the Ethiopian nation and the Solomonic throne as if they were one and inseparable.

4 Central Statistics Agency (CSA). 2007. "Summary and Statistical Reports of 2007 Population and Housing Census: Population Size by Age and Sex." FDRE Population Census Commission, December 2008, Addis Ababa.

5 The decrease in the number of Orthodox Christians is mainly attributable to the "re-conversion" of Orthodox Christians into Protestantism. The number of increase in Protestants, who were about 11\% in the 1994 census but reached to $18.6 \%$ in 2007, is roughly equal to the number of decrease in Orthodox Christians.

6 Markakis J. 1974. Ethiopia: Anatomy of Traditional Polity. London: Oxford University Press, 27.

7 Trimingham JS. 1952. Islam in Ethiopia. London: Oxford University Press, 38.

8 Erlich H. 2010. Islam and Christianity: Can They Coexist? The Answer Lies in the Horn of Africa. Boulder, CO: Lynne Rienner, 12.

9 Markakis, Ethiopia: Anatomy of Traditional Polity, 44. Ge'ez was the official language of Ethiopia until the middle of the 19th century and now used as the language of liturgy in the Ethiopian Orthodox Church (EOC).

10 Constitution of the Empire of Ethiopia, 1931 (Preamble), Revised Constitution of the Empire of Ethiopia, 1955 (article 26) Article 126 of the 1955 Revised Constitution, the 1960 Civil Code of the Empire of Ethiopia Proclamation No. 165 of 1960. The term "unholy marriage" is used to indicate the incompatibility 
This trinity of church, state, and monarchy was so intrinsic that none could be separated without destroying the others. Moreover, Ethiopia's nationhood was consciously defined in terms of religion. Those who professed Christianity were considered to be Ethiopians and all others to be non-Ethiopians. This is illustrated in Markakis's observation when he states that, "according to tradition, Ethiopian nationality is theologically defined, its primary criterion being faith. A non-Christian could not be an Ethiopian, nor could an Ethiopian adhere to any other creed." 11 This was nothing but an advancement of the myth of a "Christian island Ethiopia" agenda. Semitic culture (including the Amharic language and Christianity) were the sole criteria for acquiring Ethiopian nationality. A person had to speak Amharic and profess Christianity to be an Ethiopian. Religion, by its nature, is exclusive where it excludes non-believers and followers of other religions from its domain. The rulers deliberately coined terms like "Christian Ethiopia", "an island of Christianity"12 etc., making Ethiopian nationhood synonymous with Christianity in order to exclude the vast majority of the Ethiopian population who were non-Christians.

The overthrow of the Emperor in 1974 and the coming into power of the military regime (popularly called Derg ${ }^{13}$ ) heralded the final divorce of the state from religion and destroyed the unholy trinity of church, state, and throne. The Derg regime declared the secular socialist state of Ethiopia in which cultural, linguistic and religious equality could flourish. In practical terms, however, its religious policies were only superficial and later on focused on its atheist policies that antagonised religious communities in the country. The military junta itself was overthrown in 1991 by an ethno-nationalist force, which later came to be known as Ethiopian People's Revolutionary Democratic Front (EPRDF) and the new government further strengthened the separation of state and religion in the supreme law of the country that contributed to the constitutional equality of all religions.

\section{Islam}

Islam is the second largest religion in Ethiopia after Christianity. It consists of $34 \%$ of the country's total religious composition. ${ }^{14}$ Islam came to Ethiopia at the beginning of the seventh century $\mathrm{CE}$, which makes Ethiopia the first country in

of goals for religious and political institutions as the first is working more for the life in the hereafter while the latter for this world.

11 Markakis, Ethiopia: Anatomy of Traditional Polity, 46.

12 "The Christian Island" rhetoric is believed to be coined by the religiously "moderate" Emperor Menelik II at the end of the 19th century due to the inclusion of large numbers of Muslims and traditional believers by the war of conquest. It was advanced by Haile Selassie I with his systematic official and unofficial policies of exclusion.

13 Derg is an Amharic term to denote Committee. Derg ruled the country from 1974 to 1991 with socialism as official state ideology.

14 Central Statistics Agency (CSA), 2007. 


\section{Religion, Pluralism and Heritage in Ethiopia}

the world to accept Islam after Saudi Arabia, where the religion originated. Some scholars, such as constitutional lawyer and renowned scholar of federalism Assefa Fiseha, ${ }^{15}$ consider Ethiopia as "the first country to recognize Islam at state level in the world" substantiating his argument with mention of the Ethiopian king Nejashi, who in 615 CE welcomed the first Muslim immigrants from Arabia to his palace to practice their religion freely.

When the Prophet Mohammed and his companions faced persecution from their own Qurayish Arab tribes in Arabia, the Prophet advised them to go to Ethiopia in 615 CE. ${ }^{16}$ The Prophet told his disciples to obtain asylum from an Ethiopian king until things become stable in Arabia. Around twelve disciples (numbers are controversial, some say seventeen, others two hundred) of the Prophet arrived in Ethiopia in $615 \mathrm{CE}$, which is regarded in history as the date of the first hijrah (emigration) in Muslim history - in this case taking some of the first followers of Prophet Mohammed from Mecca to the Axumite Kingdom. ${ }^{17}$

The special status of Islam in Ethiopia is attested to by numerous writings, video and audio recordings. In a video recording by the Al-Habesha Islamic Club ${ }^{18}$ in cooperation with the Addis Ababa Islamic Affairs Supreme Council, Ethiopia has a special place in Islam mainly for the following reasons: (1) Ethiopia is the first country after Saudi Arabia to accept Islam following the first hijrah; (2) Among all the Meccan sahabas (followers), ${ }^{19}$ Bilal bin Rabah was the first black person to accept Islam and the first muezzin (prayer caller) who was of Ethiopian descent; (3) The first Muslim king was the Ethiopian king As'hama (Muslims used to call him Nejashi);20 (4) The Prophet's nurse was an Ethiopian woman named Baraka Umm Ayma; ${ }^{21}$ and (5) Ethiopia was freed from any use of force by Muslims in the words of the Prophet, "leave Abyssinians alone as long as they do not take the offensive".

15 Assefa F. 2007. Federalism and the Accommodation of Diversity in Ethiopia. Revised Edition. Nijmegen: Wolf Legal, 22.

16 Al-Habesha Islamic Club, "The historic relationship between Islam and Ethiopia", prepared by al-Habesha Islamic Club in cooperation with Addis Ababa Islamic Affairs Supreme Council. Online at: www.youtube.com, "Islam and Ethiopia (Amharic)".

17 Ahmedin J. 2011. Etyopiyawiyan Muslimoch ke 615-1700: Yechiqonana yetigil Tarik [Ethiopian Muslims from 615 to 1700: A History of Oppression and Struggle]. Fourth Edition. Addis Ababa: Merewa, 34.

18 Al-Habesha Islamic Club, "The historic relationship between Islam and Ethiopia".

19 The sahabas are those followers of the Prophet Mohammed while he was alive.

20 There are some controversies about the king's conversion to Islam. See, for example, Dereje F. 2011, 4, who states, "The EOC recognizes the coming of the companions of the Prophet Mohammed (the sahaba) to Ethiopia in 615 AD. What it rejects, and does vehemently, is the Muslims' claiming that the Christian king Armha (As'hama) who hosted the sahaba was converted to Islam." This rejection of the EOC is also corroborated by writers like Sergew Hable Selassie, Tadesse Tamirat, Trimingham and others.

21 Erlich H. 1994. Ethiopia and the Middle East. Boulder, CO: Lynne Rienner, 5. 
In light of the peaceful relations between the Muslim refugees and the Christian king of Ethiopia, the Prophet instructed his followers not to use any force against Ethiopia in the expansion of Islam. Hence, Islam was disseminated in the country through the peaceful means of missionary activities and longdistance trade. ${ }^{22}$ However, this does not mean that Muslim-Christian relations were always peaceful throughout history. There were series of conflicts and in some instances deadly clashes between them which will be discussed below.

\section{ETHIOPIA'S RELIGIOUS PAST: CONFLICTING NARRATIVES}

Contemporary Christian-Muslim relations in Ethiopia have become gradually defined by an (assumed) historical tradition of religious tolerance, rather than by the conflict model. This is, to a large degree, contested by Muslims, who maintain that coexistence was made possible only by Christian dominance and the subsequent marginalization of Muslims. ${ }^{23}$

The above quotation indicates the existence of, at least, two perspectives on Ethiopia's religious past: one is largely drawn from Muslims and the other from non-Muslims, mainly the Orthodox Christians. From the Muslims perspectives, considering Ethiopia as a model of religious tolerance were tantamount to accepting the normality of structural and institutional oppression imposed on Ethiopian Muslims and acknowledging oppression as a normal way of life. For them, there had not been religious tolerance or equality in the true sense of the term where the Muslim and Christian communities accepted religious differences as a normal social phenomenon and respected one another's faiths. However, the narratives advanced by Christian writers deliberately excluded the views of the Muslims and totally controlled the definition of "what is meant by religious tolerance in the Ethiopian context". Due to their political, economic and social dominance, Christian writers excluded the views of the Muslims who offered counter-evidence in re-writing their own history. Some Muslim as well non-Muslim writers, who tried to refute the country's Christian-oriented history and reconstruct it in a more balanced way were given nicknames as yetarik lapis (an Amharic term to mean "eraser of history").

Muslim activists and writers argue that, the history of Islam and Muslims was either not included in the general Ethiopian history, or, if included, mostly distorted and misrepresented. A Muslim activist and historian Ahmedin Jebel, for example, argues that Ethiopian Islamic history is excluded from Ethiopian history through three major strategies - selection, omission and demonisation. ${ }^{24}$ Christian Ethiopian historiographers have deliberately selected certain periods,

22 Abbink J. 1998. "An Historical-Anthropological Approach to Islam in Ethiopia: Issues of Identity and Politics", Journal of African Cultural Studies 11(2):112.

23 Desplat P and Østebø T. 2013. Muslims in Ethiopia: The Christian Legacy, Identity Politics and Islamic Reformism. London: Palgrave MacMillan, 3.

24 Ahmedin, Etyopiyawiyan Muslimoch ke 615-1700, 11-12. 


\section{Religion, Pluralism and Heritage in Ethiopia}

historical events, places and cultural phenomena which amplify the interests of the dominant group while omitting or sometimes demonising certain events and activities that have the potential to undermine Christian interests and promote the deeds of their opponents.

Muslim writers and activists challenge the religious tolerance model and forward their own alternatives as "forbearance of Muslims to the status quo better captures the religious past of Ethiopia". ${ }^{25}$ However, some contemporary foreign and domestic scholars consider it as equivalent to "re-writing the religious history of the country". ${ }^{26}$ Others, on the other hand, praise the Muslims' assertiveness as an effort to construct "a more balanced account of Ethiopia's religious past." 27

In spite of the long years of marginalisation and discrimination against Ethiopian Muslims, institutionalised by subsequent imperial rules, the longheld view of Ethiopia's religious past inclined towards the religious tolerance model that has defined the religious history of the country though contested by Muslims. It is, of course, inappropriate to put all Muslims in one box and argue that all reject the tolerance model in favor of the forbearance model. For the non-Muslims, on the other hand, Ethiopia's religious past has generally been understood to mean "tolerance and peaceful coexistence", but it would also equally wrong to include all non-Muslims in the religious tolerance model.

\section{Defining tolerance}

Tolerance can be difficult to define. The Oxford English Dictionary, eleventh edition, defines tolerance as "the ability, willingness, or capacity to tolerate something". ${ }^{28}$ It then defines the word "tolerate" as "to allow the existence or occurrence of (something that one dislikes or disagrees with) without interference; [or allow] to endure (someone or something unpleasant) with forbearance." From this definition, tolerance is understood to mean that people accept or are prepared to accept something which is different from their thinking or worldview. It is also stated in the definition that forbearance is included within the domain of tolerance. Nonetheless, tolerance is more positive than

25 Ahmedin, Etyopiyawiyan Muslimoch ke 615-1700, 11-12.

26 See, for example, Abbink Jon. 2011. "Religion in Public Spaces: Emerging MuslimChristian Polemics in Ethiopia", African Affairs 110/439:253-274.

27 Dereje F. 2011. "Accommodation, tolerance or forbearance? The politics of representing Ethiopia's religious past". Paper presented at The 4th European Conference on African Studies, Uppsala, Sweden, 1-2. Dereje wrote that "there are few countries [in the world] as burdened by their past as Ethiopia. It is no wonder thus history has been one of the major sites of political contestation." He added that "Ethiopian historiography, like history writing elsewhere, is a contested terrain. [Moreover], historiography is acutely contested particularly in countries where history is one of the cores of political legitimacy."

28 2008. Concise Oxford English Dictionary. Eleventh Edition. Oxford: Oxford University Press. 
forbearance in that the former entails restraint on both groups to respect the views of one another while the latter implies accepting oppression from one side. In forbearance, one group is forced to accept the views of the other without necessarily requiring reciprocity. The Amharic terms mechal (forbearance) and mechachal (tolerance) are used throughout this chapter to explain the Muslim forbearance and the Christian tolerance narrations respectively. In mechal (forbearance), one group is subjected to accept the superior position of another and duty-bound to respect the values of the other group. However, in mechachal (tolerance) both are equally required to respect one another.

Joan Wallach Scott, a historian who has written on conflicts over the Muslim veil in France, does not like to use words such as "tolerance" or "toleration" to express the recognition of diversity or differences since the word has negative connotations for those who are tolerated in implying their inferior position. Instead, Scott convincingly proposes that acknowledgement of differences by the state or those in power, particularly of minority groups, is a better term for capturing a sense of equality. Acknowledging differences instead of tolerating them, serves to "call into question the certainty and superiority of the established views". ${ }^{29}$ Scott recommends negotiation of differences nonhierarchically on common grounds of shared differences, since these are an unavoidable phenomenon in pluralistic social life. Others also categorise tolerance into pseudo and genuine. The former being rooted in skepticism towards others while the latter is based on "respect for truth and the dignity of others" ${ }^{30}$

\section{Religious tolerance and forbearance narratives in Ethiopia}

The religious tolerance of the past in Ethiopia is subject to different and perhaps contradictory interpretations by different groups. For some, it was mechachal (tolerance), for others it was accommodation and still for others it was mechal (forbearance). ${ }^{31}$ The Amharic term mechachal (tolerance) signifies mutual restraints from both groups (in our case Muslims and Orthodox Christians) from upsetting the other group and respect the views and religious values of others. Mechal (forbearance), on the other hand, imposes a duty on the one group to respect the other without reciprocity.

Some writings indicate that, Ethiopia is considered to be a model of religious tolerance and peaceful coexistence of Christians and Muslims. It is said that, what makes Ethiopia unique among the countries of the world is not only its early reception of the two major Abrahamic religions (Christianity and Islam), but also the unprecedented peaceful coexistence of these religions

29 Scott JW. 2007. The Politics of the Veil. Princeton, NJ: Princeton University Press, 19.

30 Tyler A. 2008. Islam, the West, and Tolerance: Conceiving Coexistence. New York: Palgrave Macmillan, 73.

31 Dereje, “Accommodation, tolerance or forbearance?", 14-19, 3-9. 


\section{Religion, Pluralism and Heritage in Ethiopia}

in the country. ${ }^{32}$ Despite this peaceful pluralistic image, scholars like Dereje Feyissa $^{33}$ identify three sets of actors advancing three competing discourses for interpreting Ethiopia's religious past - specifically, the EOC, Muslims and Ethiopian government discourses. The EOC discourse is of religious accommodation; the Muslim discourse is of forbearance; and the government is one of religious tolerance.

\section{Ethiopian Orthodox Church discourse}

The Ethiopian Orthodox Church, considering itself to be the most "indigenous" of Ethiopian religions, has always presented itself as tolerant towards other religions and that they hosted and accommodated their existence in the country. As discussed above, Orthodox Christianity entered into the country in the fourth century $\mathrm{CE}$, roughly some 300 years prior to Islam, which came in the seventh century CE. Inevitably, this historical priority, even though both came from outside, created a sense of "nativity" on the side of the EOC, while Muslims were regarded as "exotics". The "indigenous" consider themselves to be hosts - and hence accommodative - of the "newcomers". Moreover, due to the intimate relationship between the Ethiopian state and the EOC from the fourth century CE till the last quarter of the twentieth century, it created a sense of ownership on the part of the EOC of the state. It also created the impression that the survival of other religious communities depended, to a large degree, upon the goodwill of the EOC. The EOC also possessed a third of the land of Ethiopia and the power to bless and anoint emperors to govern the people. The symbiotic relationship between the emperors and the EOC gave the latter the clout to exclude other religious competitors from the field, unless it chooses to accommodate them. In this regard, accommodation of different religious communities was largely attributable to the "high moral ground" of the EOC, ${ }^{34}$ and is considered as one of the defining features of Ethiopia's religious past.

Accommodation, however, entails a meaning of "superior position", and if the need arises, it could eliminate others by withdrawing its accommodation. Thus, accommodation, like forbearance, does not encompass mutual coexistence, but rather the will of the "dominant group" as a precondition for others to survive. Even so, the EOC usually narrates Ethiopia's religious past in terms of accommodation, so much so that, the EOC is praised for its "generosity" in accommodating Muslims and other Christian denominations by its own will.

32 Ewunetu Yih New [This is the Truth]. 2012. Lehizbe Muslimu Weqtawi Tiyaqewech Meftihe Lemafelaleg Yetemeretew Komitie Yasalefachew Hidetochina Lemengistina Lebaledirsha Akalat Yasigebachew Ye-Abetuta Debdabewech Sibsib. Unpublished Collection Works of the Muslims' Solution Finding Committee, 6.

33 Dereje, "Accommodation, tolerance or forbearance?", 2.

34 Dereje, "Accommodation, tolerance or forbearance?", 4. 


\title{
Ethiopian government discourse
}

The incumbent government of Ethiopia explains Muslim-Christian relations in terms of mutual tolerance in a way that, to some extent, resembles the EOC's narrative of accommodation. ${ }^{35}$ Through state media and various policy documents, ${ }^{36}$ the government has advanced the discourse of religious tolerance as the defining feature of Ethiopia's religious past. In so doing, it has been able to re-enforce a myth of religious tolerance and to portray religious tolerance as the unique trademark of Ethiopia to be exported to the rest of the world, which suffers from the infections of religious intolerance and conflict. ${ }^{37}$

The EPRDF government always praises the Ethiopian experience in terms of peaceful coexistence and romanticised the past as mutual tolerance among different religious groups. The government acknowledges the misdeeds of Ethiopian rulers, but the people are usually described as displaying cooperation and respect to one another which has no parallel in other parts of the world. In a 2011 document entitled, Yehaimanot Akrarinetinina Yegosa Gichitochin Yeminfetabet Agerawi Eqid Meneshawechina Aqitachawech (A National Plan, Bases and Directions to Solve Religious Extremism and Ethnic Conflicts), the government maintained that:

\begin{abstract}
Although there were conflicts for power, territorial expansion and controlling trade routes in Ethiopia under the cover of religion, the Ethiopian people always exhibited mutual religious tolerance, respect and cooperation that made us [Ethiopians] proud. While rulers struggled for their own interests, our people displayed religious tolerance and cooperation that can be transmitted from generation to generation and lived peacefully for centuries in one roof..$^{38}$
\end{abstract}

The culture and history of religious tolerance practiced for centuries in Ethiopia can, according to this view, be taken as an exemplary model for other countries. While the EPRDF-led government designated all Ethiopian emperors, with few exceptions, as "nation-destroyers", who destroyed nationalities and peoples in the name of "nation-building", it never mentioned the religious misdeeds of the rulers for fear of stoking religious tensions. The EPDRF's current religious tolerance discourse can, therefore, be challenged as to its "sincerity" and its use and misuse of history to its own advantage. The government has a strategy of deconstructing and reconstructing Ethiopian history in its own favour. It is a

35 Addis Raey. 2012. Adis Raey Ginbot-Sene 2004 [Addis Raey from May to June 2011]. 2nd Year, 3(9).

36 "Yehaimanot Akrarinetinina Yegosa Gichitochin Yeminfetabet Agerawi Eqid Meneshawechina Aqitachawech [A National Plan, Bases and Directions to Solve Religious Extremism and Ethnic Conflicts]". 2011. Unpublished Government Document prepared for creating awareness for government officials.

37 Prime Minister Meles Zenawi's speech to the FDRE Parliament, 17 April 2012.

38 "Yehaimanot Akrarinetinina Yegosa Gichitochin Yeminfetabet Agerawi Eqid Meneshawechina Aqitachawech", 3. 


\section{Religion, Pluralism and Heritage in Ethiopia}

meaning imposed on a phenomenon that takes political advantage of power at the centre, despite being contested by some groups. ${ }^{39}$

The religious tolerance narrative, which Muslim activists and elites see as being advanced by the government, lacks sincerity because it provides no empirical evidence of past deeds and it is used only to deflect the contemporary legitimate claims of Muslims for religious parity and freedom, equating their demands with religious intolerance and extremism. The deliberate use of Ethiopia's past religious history as a history of religious tolerance and mutual peaceful coexistence is a tactic of the government to label the present Muslim generation as fundamentalist and extremist. Put differently, the end result of the past religious tolerance discourse is to interpret the Muslim activists' protest or movement for more freedom and rights as a sign of religious fundamentalism, intolerance of diversity, and a threat to the present and future of Ethiopia's unity. The terms Islamic fundamentalism and extremism and the logical steps that flow from "fighting terrorism" is used deliberately by the government to crackdown on Muslim protest and to delegitimise the demands of Muslims for independent Islamic institutions and religious equality and non-interference in their religious affairs. The myth of the history of Ethiopia's religious tolerance is widely contrasted by the government discourse with the intolerant practices and actions of Muslim activists of the present generation.

\section{Muslim discourse}

For many Muslims, it was mechal (forbearance) of Muslims to the political, social, economic and cultural domination of Christians that explains better Ethiopia's religious past than accommodation and mechachal (tolerance). ${ }^{40}$ One of my interviewees described the relationship between Muslims and Christians or otherwise the state in three ways: submissiveness, fatigue (exhaustion) and tolerance.$^{41}$ In my interviewee's view, it is the first and to some extent the second scenario that better explains Ethiopia's religious past, in which Muslims submitted to Christian superiority and accepted the status quo with minimal or no challenge. So long as Muslims remained subordinate to the Christiandominated state and accepted it without contest, the state tolerated them for the economic advantage they could provide - for example, by engaging in trade, which was despised by Christians at the time, or by providing cheap labour for the land owners. ${ }^{42}$ The fatigue or exhaustion, my interviewee ${ }^{43}$ explained, is related to the exhaustion of the two religious communities to engage in constant competition where their numbers are equivalent in some parts of the

39 Addis Raey Megazin [New Vision Magazine]. 1998.

40 Ahmedin, Etyopiyawiyan Muslimoch ke 615-1700.

41 Interview with Mohammed Ali by MD Assen, Addis Ababa University, 14 June 2014.

42 Hussein, "Coexistence and/or Confrontation?"

43 Interview with Mohammed Ali. 
country. He mentioned Wollo as an example of where Muslims and Christians came to terms with one another to live in de facto peace out of a realisation that it could be disastrous to go into conflict. The third stance of tolerance, for him, was a means toward mutual understanding of differences and respect for one another's identity. In his view, this had never happened in Ethiopia, outside of the official rhetoric advanced by the government and the EOC. For Muslim activists, therefore, the government's narrative of the past as a model of religious tolerance is interpreted as "pressing them to accept the status quo meaning the religious inequality and their second-class status and undermining the legitimate demands of Ethiopian Muslims". ${ }^{44}$

Taking into account the views of various actors, particularly the Muslims, some writers question whether Ethiopia's religious past was really mechachal (tolerance) or mechal (forbearance). ${ }^{45}$ For Muslims, it was the total submission to hegemonic rule by the Christian kings and acceptance of their marginalised status that maintained peaceful coexistence between the two communities. This situation could not be interpreted as religious tolerance on the basis of equality. Ahmedin Jebel, for example, out-rightly rejects the religious tolerance narratives forwarded by the state media, government and other sources, which simply amplify the religious tolerance message without corroborating through empirical evidence that support their claims. Ahmedin argues that, Muslims "tolerated" the Christian domination and accepted their subordinate status in the Ethiopian body politic. ${ }^{46}$

Orthodox Christianity was always a state religion, from its first appearance in the fourth century to the 1974 popular revolution that swept away the last imperial government. Inevitably, other religions were subordinated and their followers were regarded as second-class subjects, even aliens. ${ }^{47}$ In the period from the seventh century to the end of the twentieth century, Islam was seen as a religion of "non-privileged" people and Muslims were destined for secondclass status. Muslims were only a useful source of revenue for the imperial governments and linkage with the outside Muslim world, but Muslims should remain impotent in domestic political and social affairs. Muslims were denied access to land ownership, and they were prevented from serving in the army and participating in political and social affairs. They were not allowed to build mosques and celebrate their religious holidays publicly. Muslims were only involved in trade and other "low status" activities like weaving, woodworking and trade, since these activities were despised by Christian elites and commoners. ${ }^{48}$ Christians, on the other hand, participated in the so-called "privileged activities", such as farming, soldiery and in governmental posts

44 Dereje, "Accommodation, tolerance or forbearance?", 20.

45 Dereje, "Accommodation, tolerance or forbearance?".

46 Ahmedin, Etyopiyawiyan Muslimoch ke 615-1700, 30.

47 Hussein, "Coexistence and/or Confrontation?", 6.

48 Hussein, "Coexistence and/or Confrontation?", 6. 


\section{Religion, Pluralism and Heritage in Ethiopia}

as civil servants and political appointees. ${ }^{49}$ Muslims were deprived of land to plough, and prohibited from working in government offices or becoming soldiers, unless they were converted to Christianity. ${ }^{50}$ All these were done through the collaborative effort of the Ethiopian state and the EOC.

Arguably, Ethiopia's religious past was seen superficially through the lens of the religious accommodation and tolerance narratives without critically examining the reality on the ground. Rhetorically, it was portrayed as an ideal example of religious tolerance in the world and even to be exported to other nations - but this narrative only amplifies one side of the story without fully appraising the views of the other.

\section{NEW TRENDS OF RELIGIOUS (IN)TOLERANCE}

Once seemingly taboo claims in Ethiopian history started to be raised by Ethiopian Muslims in post-1991 Ethiopia. Muslims of Axum, who constitute around $11 \%$ of the total population of the town, ${ }^{51}$ along with Lalibela - both of which are perceived to be Christian "holy places" by the EOC - invoked their constitutional rights and requested plots of land from the local governments to establish mosques. The EOC vehemently opposed these demands, stating that these places are "sacred places" for the Christians. Hence, according to the views of Christians, Muslims should not be allowed to construct mosques in Christian holy lands as "Mecca would not allow the construction of any Church there" ${ }^{52}$ The analogy between Mecca and Axum is weak - for one thing, the practice of prohibiting Christians from constructing churches in Saudi Arabia is unjust and criticised by almost all democratic states, and for the other, the laws of Saudi Arabia and federal Ethiopia are different, which makes Saudi Arabia irrelevant for the debate in Axum and Lalibela. It does, however, indicate that the EOC considers Axum to be its "exclusive property" which "others" (Muslims, Protestants, Catholics, Jews, etc.) have no right to claim, irrespective of their numbers of believers in the vicinity.

It is to be remembered that, Axum was the first place in the world to receive Muslim refugees from Arabia and King As'hama (Nejashi, according to his Muslim name) was the first Christian king on earth to allow Muslim asylum-seekers to live peacefully in his kingdom. It is the first instance of peaceful coexistence between the two monotheistic religions. The current "Axum Paradox"53 mainly emanates from the "wrong" assumption about the

49 Abbink, "An Historical-Anthropological Approach to Islam in Ethiopia", 112.

50 Markakis, Ethiopia. Anatomy of Traditional Polity, 63.

51 Dereje F. 2013. "Religious Conflict Analysis in Ethiopia". Research Report Submitted to the Norwegian Church Aid. Unpublished, 3.

52 Dereje, "Religious Conflict Analysis in Ethiopia".

53 The term "Axum Paradox" is my own usage to show the paradox which happened in Axum town with regard to Muslim-Christian peaceful coexistence in the past and today. In history, Axum Christian leaders were best remembered in Muslim narratives as accommodative for Muslim asylum-seekers from Arabia 
prohibition of construction of mosques in a historically Christian "holy land" where the Ark of the Covenant is placed. Ironically, Axum is also claimed by Muslims as their holy land historically, since the first companions of the Prophet Mohammed practiced Islam freely in the Axumite kingdom and some Muslims are buried in and around the city of Axum. The tomb of Nejashi is found near the town that many Muslims visit every year as a local hajj or pilgrimage.

Although not fully substantiated by evidence, "nearly all members of the EOC believe that the original Ark of the Covenant is hidden in the Axum Zion Church in northern Ethiopia", ${ }^{44}$ and that it was brought by Emperor Menelik I from Solomon's Temple in Jerusalem - this is the origin of the Solomonic myth. ${ }^{55}$ Of course, no one has ever seen the Ark, but "believing without seeing", as the religion orders its believers to do, has prevailed.

In an interview conducted by Ahmedin Jebel with local Axum Muslims, they complained that "Muslims of Axum are prevented from constructing mosques in and around the city". ${ }^{56}$ The prohibition of mosque construction extends up to an $18 \mathrm{~km}$ radius from the town.$^{57}$ The reasons for prohibiting Muslims from building mosques, as the interviewees said, were that the Christians opposed it, because in their perspective "Axum is a town of the historical Axum Zion Church and the land of Muse Zion". ${ }^{58}$ The Christian tradition regards Axum as "the second Jerusalem, where God's Ark came to rest". ${ }^{59}$ However, historian Wudu Tafete argues that, "the principal objective of this 'invented tradition', formulated by the church, was to give political legitimacy to the 'Solomonic dynasty, which came to power in 1270 " ${ }^{60}$ From the Christians' perspective, it is only wasting money and time for Muslims to seek to establish their worshipping houses in a "Christian holy land"61 The Muslims of Axum are, therefore, forced to pray in private houses which are given for the Friday congregational prayer as waqf, meaning voluntary donation by Muslims of use of their own houses. The belief that Axum is a holy place for Christians originates from the aforementioned assumption, but it has nothing to do with the location of the area.

and respectful of the religion of Muslims. Today, the same Axum is becoming less accommodative of the claims of Muslims and the local rulers in the town are less responsive to the claims of Muslims for plots of land to construct mosques.

54 Craig EJ. 2010. Haile Selassie and the Religious Field: Generative Structuralism and Christian Mission in Ethiopia, MA Thesis, Temple University, 22.

55 Erlich, Ethiopia and the Middle East, 22.

56 Interview with local Muslims of Axum by A Jebel, 2009. Yemuslimoch Guday Metsihet [Muslims' Affairs Magazine] 1(1):31-33.

57 Dereje, "Religious Conflict Analysis in Ethiopia", 3.

58 Yemuslimoch Guday Metsihet [Muslims' Affairs Magazine]. 2012. Ummu Ayman Publishing and Advertisement Private Ltd. Co., 1(1):12.

59 Wudu TK. 2006. The Ethiopian Orthodox Church, the Ethiopian State and the Alexandrian See: Indigenizing the Episcopacy and Forging National Identity, 1926-1991, PhD Diss, University of Illinois, 7.

60 Wudu, The Ethiopian Orthodox Church, the Ethiopian State and the Alexandrian See.

61 Interview with local Muslims of Axum by A Jebel. 


\section{Religion, Pluralism and Heritage in Ethiopia}

Moreover, there are different sayings in Ethiopia which have their own implications for the Axum controversy over securing land for Muslim worshipping houses. As stated earlier, Muslims have been totally prohibited from acquiring land for a living, let alone for mosques. That is why most Muslims today still pursue trade over other activities. An old Amharic saying in the community illustrates how difficult accessing land was for Ethiopian Muslims: "Yemuslim hageru Mecca, Yewef hageru warka" - literally "A Muslim's land is Mecca, as a bird dwells on a tree". The saying implies that, there is no place for Muslims in Ethiopia. It is only in Mecca that Muslims can claim their land to construct a mosque. This saying, however, does not work in present-day Ethiopia, especially since the overthrow of Emperor Haile Selassie in 1974. The military Derg regime redistributed the land of Ethiopia owned by feudal lords to the Ethiopian people, irrespective of their religious and ethnic background. Ethiopian Muslims benefited from that policy like many other poor peoples of the country. The 1991 regime change further consolidated the rights of groups and individuals to access land for different purposes, including land for the construction of houses of worship, irrespective of the location within the country. The Ethiopian laws, particularly those laws enacted after 1991, allowed the construction of mosques or churches for believers irrespective of the location, so long as legal procedures are followed. The Constitution of the Federal Democratic Republic of Ethiopia provides in Article 27(2) that "believers may establish institutions of religious education and administration in order to propagate and organize their religion." 62 This right is only restricted to keep education secular and free from "religion, political partisanship or cultural prejudices. ${ }^{63}$ It does not prohibit the construction of mosques or churches for the mere reason of the area being regarded as a "holy place" by Christians or Muslims.

The local governments of the regional states of Amhara and Tigray reacted in a mixed way that did not prohibit, but also did not allow, the Muslims to build mosques. The regional governments are aware of the rights of Muslims, but are also trying not to disappoint Christians, particularly the powerful EOC. Despite their efforts not to openly deny access to land for Muslims of Axum and Lalibela, which would violate their constitutional rights, their silence in response to the requests of Muslims amount to denial. The statement made by the United States State Department in 2007 best illustrates the denial of land for the Muslims of Axum and Lalibela to construct mosques:

Local authorities in the northern town of Axum, a holy city for EOC, continued to deny Muslim leaders' repeated requests to allocate land for the construction of a mosque, even though the Constitution provides for freedom to establish institutions of religious education and administration. Tigray and Amhara regional government officials

62 Constitution of Federal Democratic Republic of Ethiopia (FDRE), Proclamation No. 1/1995.

63 Constitution of the Federal Democratic Republic of Ethiopia, art 90 sub art 2. 
choose not to interpret this provision liberally in the towns of Axum and Lalibela respectively and the Federal Government did not overrule them. ${ }^{64}$

The denial of plots of land for mosque construction in Axum and Lalibela is not without a backlash effect on Christians in the southern and eastern parts of Ethiopia, where Muslims are numerically dominant. Muslims raised another weak but similar logic with their Christian counterparts, claiming that, Harar and Jimma are "holy places" for Muslims and hence Christians should not be allowed to construct churches. Some even went to the extreme demanding that, "the already constructed churches should be demolished from these areas." 65

With regard to the denial of plots of land for the construction of mosques, Hussein Ahmed even argues that, it is not only in Axum and Lalibela that Muslims faced opposition from the EOC and ordinary Christian residents for constructing mosques but in all parts of the country. On this point, he noted that:

The construction of almost all the major mosques in Addis Ababa (and those elsewhere in the country) was invariably preceded by opposition from the Christian residents and churches of the areas in which the mosques were intended to be built, and a protracted legal battle with the government departments responsible for granting the plots of land, issuing the necessary title deeds and the permission for construction. ${ }^{66}$

Even after securing permission from relevant authorities to construct mosques, their heights were limited to a certain number of meters in order not to create psychological influence over the residents and to hide the visibility of Muslim presence. For example, minarets were not allowed to be constructed, in order to keep mosques as short as possible and to limit the reach of the muezzin's prayer call to a very short distance. As Hussein puts it, the minaret of Nur Mosque in Addis Ababa was added much later after its construction since the rulers of the time were unhappy to see Muslim presence in the heart of the capital "dominating the city's skyline". ${ }^{67}$

In the construction of mosques, Muslims nearly always face popular protest, bureaucratic delay and obstruction. In many instances, this has led to violence and open conflict with the Christian community. A case in point was the problem that occurred during the construction of Gullele Mosque in Addis Ababa. While Muslims started constructing the mosque in the 1980s, work was suspended due to opposition from the nearby church. Moreover, the rulers of the vicinity claimed that the site was chosen for the construction of a school.

64 2011. "Where is Justice for the Muslims of Axum? Ethiopian Muslims from Tigray-Diaspora", Badr Magazine, 25.

65 Interview with former local official in Jimma town currently residing in Addis Ababa by MD Assen, 26 November 2014.

66 Hussein, "Coexistence and/or Confrontation?", 12.

67 Hussein, "Coexistence and/or Confrontation?". 


\section{Religion, Pluralism and Heritage in Ethiopia}

The construction of the mosque was then delayed for years and was resumed only after the coming to power of EPRDF in the 1990s. ${ }^{68}$

In an informal discussion with a 70-year-old Muslim elder in Nefas Silk Lafto, a sub-city of Addis Ababa, he remembers some of the opposition they faced in the construction of mosques during the last days of Emperor Haile Selassie I. ${ }^{69} \mathrm{My}$ interviewee came to Addis Ababa from Wollo in 1972 with his elder brother. Upon their arrival, they settled around the outskirts of the city constructing "slum" houses from plastic and wood. As he remembers, they had very nice Christian neighbours who invited them over to drink coffee during Christian holy days. However, considering the lower status of Muslims in the public, their neighbours always exerted pressure on them to convert to Christianity, saying "why don't you convert to Christianity for us to eat meat together?"70 They resisted the pressure and remained Muslim. As he reported, gradually many more Muslims came to the area from different parts of the country to settle. They secured permission from the governor of the area to construct a mosque, but they faced strong opposition from the local Christian residents. When they started construction, Christian residents all of a sudden built a "house" on the same site during the night, what is publicly called as yechereqa bet - literally "moon-house" to show its illegal nature constructed at night using the light of the moon. Subsequently, Christians claimed the property to construct a church. Due to the conflict between the Muslims and the Christians, the construction of both groups was delayed for a while. The revolution came in 1974 before the dispute was settled, and the Muslims initiated the matter for decision by the new Derg officials. The Christians also claimed the area. Finally, the problem was settled by providing two plots of land, one for the mosque and the other for the church. Today, the mosque and the church stand side-by-side as "living witnesses".

Compared with the past, the acquisition of land for the construction of mosques has become relatively easier under the EPRDF government. Although some problems of bureaucratic bottlenecks and popular protests persist, Muslims are in a far better position in both legal and practical terms to satisfy their spiritual needs. In the last two decades (1991-2010), the government and Ethiopian Muslims have had generally good relations. Muslims appreciate the efforts of the government in guaranteeing their religious rights and are supportive of the government.

\section{CONCLUSION}

The religious tolerance narrative of Ethiopia's religious past is complex to understand, since it is understood in different ways even among Muslims

68 Hussein, "Coexistence and/or Confrontation?", 6.

69 Interview with Sheikh Endris by MD Assen, 2012.

70 Based on Ethiopian tradition, Muslims and Christians could not eat together meat slaughtered by a person of the other faith. 
themselves. In the long history of Ethiopia, religious tolerance and peaceful coexistence of Muslims and Christians were more prevalent than conflict, but mainly owing to the submissiveness of Ethiopian Muslims and the deliberate action of the successive rulers of the country to make Muslims politically impotent. In one way or another, all the rulers of Ethiopia employed different mechanisms to discourage and possibly eliminate Islam from the country until the 1991 regime change. Some used openly aggressive policies and forced conversion, whereas others pursued a more systematic way of eliminating Islam in the name of pseudo-religious tolerance policies. The intolerant faces of Christian elites were observed several times when Muslims asserted their rights and became politically aware.

In sum, in the long history of Muslim-Christian coexistence, tolerance and forbearance were the common features of Ethiopia's religious past. At the state level, Muslims were denied access to land, government positions and important economic sectors, but at the same time they were tolerated as long as the Christian dominance was unchallenged. There have been legal and practical improvements in the post-1991 Ethiopia but tensions are high between the two religious communities regarding control over the public space. This in turn affects peaceful coexistence negatively. 